\title{
Risks of transmissible diseases in relation to embryo transfer
}

\author{
Bertrand Le TALLEC ${ }^{\mathrm{a} *}$, Claire PonsART ${ }^{\mathrm{b}}$, \\ Brigitte MARQuant-Le GuIENNE ${ }^{\mathrm{b}}$, Bernard GuÉRIN ${ }^{\mathrm{ab}}$ \\ ${ }^{a}$ Laboratoire National de Contrôle des Reproducteurs, 13 rue Jouët, BP 65, \\ 94703 Maisons-Alfort, France \\ b UNCEIA, 13 rue Jouët, BP 65, 94703 Maisons-Alfort, France
}

(Received 15 October 2001; accepted 5 November 2001)

\begin{abstract}
Realizing the potential of Embryo transfer (ET) for rapid, cheap and widespread dissemination of genetic material, the risk of transmission disease through the embryos must be considered. The aim of this paper is to evaluate theses risks at each step of production, storage and transfer. The pathogen agent may potentially originate from the donor male (semen) or the donor female (oocytes, embryos) and finally from the environmental conditions. As the differences between in vivo and in vitro derived embryos have been well described, evaluation of the potential risks should be assessed separately for in vivo and in vitro produced embryos. Even if this paper insist on the diseases or diseases agents that are more questionable, it clearly appears that ET remains the more safety way to transfer gene, provided prevention measures are properly handled (use of donor that are specific pathogen free, washing of embryos, additional treatment...) and furthermore it can be easily seen as the best way to prevent some disease transmissions (TSEs, leukosis, foot-and-mouth disease...).
\end{abstract}

embryo transfer / disease transmission / sanitary control / in vitro fertilization

\section{INTRODUCTION}

Initially limited to national or international trade of live animals or semen, the exchanges of genes are now widely associated with embryo transfer. This biotechnology which is mainly used to rapidly improve genetic potential is not a way of transmission of different infectious diseases. Indeed, some epidemiological studies of numerous infectious diseases (i.e. Maedi-Visna or more recently infectious bovine rhinotracheitis (IBR), foot-and-mouth disease (FMD), porcine reproductive and respiratory

\footnotetext{
* Correspondence and reprints

E-mail: b.letallec@lncr.org
} 
syndrome (PRRS) clearly highlight the close relationship between the importation of infected animals in a free country and the resulting spread of the disease. Therefore, to avoid this kind of disease transmission, the perfect knowledge and the assessment of the sanitary risks associated with embryo production and embryo transfer are of highest interest for scientists and veterinary authorities. The aim of this article is to evaluate these risks by using the Hazard Analysis Critical Control Point (HACCP) method that is commonly used in the food industry. This means that the risk of disease transmission must be evaluated at each step of embryo production, storage and transfer. Then, we should be able to focus our attention on the critical points, to evaluate or define new procedures that would enable us to deal with the potential risks and either to answer specific questions like this one "when we are facing a sanitary problem (bovine spongiform encephalopathy (BSE), footand-mouth disease (FMD), tuberculosis, brucellosis...) in a herd of high genetic merit, can we collect oocytes or embryos?" In other words, can the ET be a way to save the genetics of a herd?

In vivo and in vitro produced embryos may be contaminated during the different steps of production and transfer. The pathogenic agent may potentially originate from the donor male (semen) or the donor female (oocytes, embryos). It can be present in various environments, such as serum or media used for the handling of oocytes and embryos, in vitro maturation of oocytes, in vitro fertilization and culture. Pathogens may also be added during the whole process of embryo production, from collection to transfer, including storage conditions.

Thus we will investigate the risks of disease transmission at each stage of the embryo production and evaluate the prevention measures. In order to obtain a good assessment of the sanitary aspects associated with embryo transfer, we should have and use both experimental and field data.

\section{SANITARY RISKS ASSOCIATED WITH SEMEN}

A lot of pathogenic organisms are present in the genital glands or testis, in the lymphatic system, in the blood system (during a bacteremia or a viremia) or in the urinary system. Therefore, all of these microorganisms may be easily transmitted in the semen by the way of seminal liquid, sperm, or with urine contact. This is confirmed by the fact that nearly all of the pathogenic microorganisms listed in the OIE have been isolated from semen.

\subsection{An approach with three examples}

\subsubsection{Mycobacterium paratuberculosis}

When a pathogen agent is not detected in semen, we should wonder if the test we used to detect it is enough sensitive. For instance, there was no evidence of semen excretion of Mycobacterium paratuberculosis during several years, because of the dilution of semen in the extender and the low concentration of this pathogen in semen $[37,38]$. The semen excretion could be confirmed with more sensitive tests such as polymerase chain reaction or enhanced culture systems.

These microorganisms (virus or bacteria) can be present intermittently in semen (Fig. 1) either in seminal plasma and/or associated with spermatozoa [61]. This contamination can play a role during fertilization and can also be transmitted to the embryo or to the recipient.

\subsubsection{Bovine Viral Diarrhoea Virus $(\boldsymbol{B} V \boldsymbol{D V})$}

A very high viral load can be found in semen due to replication of the virus in the reproductive tract of the bull [34] and as freezing does not kill the virus, an inseminated cow will be inevitably infected by a contaminated semen. Kirkland et al. [35] 


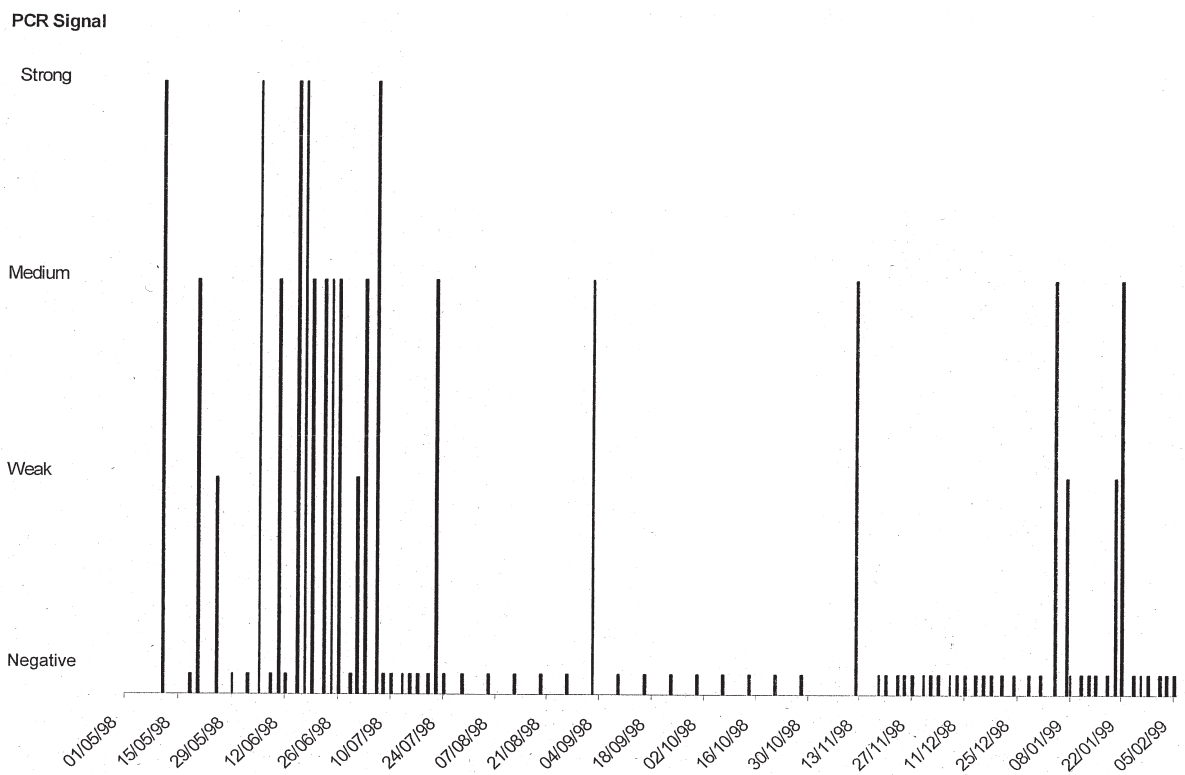

Figure 1. Detection of DNA of M. paratuberculosis in bull semen by PCR test during 9 months.

show that even with a semen from a transiently infected bull, BVDV could be transmitted to inseminated cows. Moreover, Bielansky et al. [12], did not succeed in removing BVDV from bull semen and according to Guérin [1, 30, 32], this contamination has an important effect on every early embryonic mortality even if this negative effect on in vitro development rate may depend on the virus strain and on its cytopathic effect [6].

\subsubsection{Mycoplasma spp.}

Bielansky et al. [19] performed in-vitro fertilization with semen experimentally infected with Mycoplasma bovis or Mycoplasma bovigenitalium and showed that these pathogens can be transmitted through the IVF system and therefore infect the embryos. Furthermore, their experiments showed that the supplementation of the media used for in vitro culture with standard antibiotics and the washing procedure of the embryos as recommended by IETS were not effective in rendering IVF embryos free from $M$. bovis and $M$. bovigenitalium.

\subsection{Conclusion}

In fact, the different studies testing contamination of in vitro or in vivo produced embryos show that the risk of transmission of pathogenic microorganisms when using infected semen is potentially very high.

\subsection{Prevention measures}

In order to avoid contamination of semen and to control related sanitary risks, different measures have to be taken. The first one and the most important one is the epidemiological rule specifically applied in AI centres: the only way to be sure that produced semen is pathogen free is by using a bull whose historical sanitary status is very well known: this bull is living in a pathogenic 
free centre where all animals are free from disease and regularly controlled. Before its entry to the AI centre it has been remained a couple of month in the station where it has been tested at least two times. Moreover, before this quarantine it had been come from an non infected herd. If this rule cannot be achieved and if a bull with high genetic merit has to be used for ET, the only way to lower the risk of contamination (without eliminating it) is to examine each ejaculate by testing a couple of straws with a sensitive test.

Besides these major pathogens for which males are strictly controlled in AI centers, semen can be contaminated by other species, such as ubiquitous pathogens. This contamination may be limited by hygienic measures which are applied especially on housing, collection and processing of semen. The respect of these sanitary procedures may be verified by the sanitary rule linked to the ability to produce semen of high microbiological quality $\left(<500 \mathrm{CFU} \cdot \mathrm{mL}^{-1}\right)$. Addition of antibiotics to the extenders are also efficient to limit the number of bacteria present in the extended semen.

\section{SANITARY RISKS ASSOCIATED WITH THE DONOR FEMALE}

\subsection{In vivo produced embryos}

Oocytes and embryos are surrounded by the zona-pellucida ( $\mathrm{ZP})$, which protects the embryos and plays a role during all the phases of embryonic development, from maturation through fertilization until early embryonic development. In general, the ZP of mammalian species is composed of $3 \mathrm{gly}-$ coproteins, which are assembled in a complex three-dimensional structure. Changes in the structure of the glycoproteins occur during fertilization and also during the passage of the embryo through the oviduct. As a consequence, pathogens can no longer bind to and/or penetrate the intact ZP after fertilization, which becomes an effective barrier against contamination by most of the pathogens investigated. Therefore, the main parameter is related to the integrity of the $\mathrm{ZP}$ and it is generally accepted that the only way of transmission of pathogens to recipients is via adhesion to the ZP [54]. Nevertheless, it must be taken into account that adhesion characteristics depend on the pathogens as well as species.

In cattle, the Foot-and-mouth virus [40, 41, 49], Bluetongue virus [23, 56], brucellosis [3, 25, 51, 52], tuberculosis [18] and enzootic bovine leukosis [26] do not seem to represent any risk of transmission by ET. On the contrary, the risks associated with Mycobacterium paratuberculosis, the Bovine herpes virus-1 and non conventional agents such as prions are more questionable.

\subsubsection{Mycobacterium paratuberculosis}

As far as I am concerned, only one experiment [46] has been done to assess the sanitary risk between embryos and $M$. paratuberculosis. In this experiment, 50 Zona pellucida intact embryos were incubated with 5 different concentrations of $M$. paratuberculosis ( 1 to $10^{4} \mathrm{pfu} \cdot \mathrm{mL}^{-1}$ ) during 12 hours at a temperature of $22{ }^{\circ} \mathrm{C}$. The result of the culture is that even after ten washes, from 10 to $50 \%$ of the embryos remained contaminated according to the bacterial concentration used in the incubation.

\subsubsection{Bovine herpes virus-1}

For Bovine herpes virus-1, the virus ability to attach the zona pellucida was highlighted for the first time after in vitro studies [48]. Indeed, BHV-1 was isolated in follicular fluid, follicular cells, oocytes and embryos after experimental infection of donor cows [31]. In that context, the related risk could be considered as high. However, field data on embryos exported in France over many years indicated that none of the recipients of embryos seroconverted even though some of the donors from which the 
embryos had been collected were positive for antibodies [55]. Moreover, it has been shown that all viral particles are eliminated after the IETS washing procedures with trypsin [53]. As a consequence, if no transmission of pathogens to recipients is observed after transfer, the risk associated with transfer of embryos from infected donors can be considered to be negligible. These results have finally led to the following conclusion: Ruminant $\mathrm{ZP}$ intact embryos do not appear to be a vehicle for the transmission of IBR.

\subsubsection{What about Transmissible Spongiform Encephalopathies?}

For scrapie, conflicting results have been obtained. The results of three studies about embryo transfer between scrapie infected sheep and scrapie free sheep are presented in Table I.

Although the last experiment was a natural infection, the both first were experimental ones. The first one is led by Foster in Scotland in 1992. The result suggests that embryos, after no washing might carry disease into the offspring. But Foster designed this experiment as "the worst case scenario" because not only none of the embryos were washed but the embryos donors were of susceptible genotype and had previously been challenged with a high virulent inoculum. In the second case, in the USA, Foote did not found any evidence for transmission with 3 out of 10 recommended washes. So, in 1993, despite the considerable research already performed the question whether scrapie may be transmitted by embryos remained unanswered. But now, a very recent study led by the same American team confirm its previous result by showing that no transmission can occur after transfer of embryo from naturally infected donors to free recipients. Moreover, it is concluded that "Embryo Transfer can prevent vertical transmission of scrapie" [63].

\subsubsection{Bovine Spongiform Encephalopathy (BSE)}

Turning to BSE, the only existing data on the contamination of the embryos is the great british experiment conducted by Wrathall in UK. It began in 1990 with a sample of 167 infected cows and inseminated with 8 BSE positive bulls and five healthy bulls. He collected the embryos, washed them, observing the IETS standards and evaluate the embryos infectivity by two types of experiments: mice bio assays and embryo transfer into heifers imported from New-Zealand.

The results that have been partly published show that neither the embryos nor the flush fluids contained detectable BSE infectivity, assessed by injections in BSEsusceptible strains of mice [64, 65]. In 1997, there was no evidence of BSE in the recipients and in their embryo transfer offspring, but the absence of transmission of BSE via ET has to be confirmed by complementary results.

Table I. Data on the risk of scrapie transmission via ET.

\begin{tabular}{lcccccc}
\hline & Infection & $\begin{array}{c}\text { Number } \\
\text { of ewes }\end{array}$ & $\begin{array}{c}\text { Time* of embryo } \\
\text { collection }\end{array}$ & $\begin{array}{c}\text { Clinical signs after } \\
\text { embryo collection }\end{array}$ & $\begin{array}{c}\text { Washings } \\
\text { Infected } \\
\text { lambs }\end{array}$ \\
\hline Foster [28] & Exp. & 6 & 6 & $1-3$ months & 0 & $6 / 26^{* *}$ \\
Foote [27] & Exp. & 74 & $3-21$ & $6-35$ months & 3 & $0 / 67$ \\
Wang and Foote [63] & Nat. & 38 & & & 10 & $0 / 94$ \\
\hline
\end{tabular}

\footnotetext{
* Months after experimental infection.

** Born pApA Sip recipients.
} 
In goats, there is no evidence of transmission of the BSE agent to the offspring via ET: Foster et al. [29] observed that in vivo embryos collected from donors which were experimentally infected with BSE and transferred into BSE-free recipients did not develop TSE-like-disease.

Thus, for both TSEs diseases, according to the last experiments, the risk seems quite negligible provided that the IETS recommendations are respected.

As a conclusion with the sanitary risks related to in vivo produced embryos, ZP especially of in vivo production embryos act as a barrier for the majority of the disease (enzootic bovine leucosis, foot and mouth disease, blue tongue, brucella abortus...)

But few agents, such as $M$. paratuberculosis, can attach themselves to the exterior of the ZP. This is true especially in the case of some enveloped virus like Herpes virus and also few bacteria like Heamophilus somnus [57], Ureaplasmas [24], Mycoplasmas [12] or Escherichia coli [44]. Indeed, the 10 washes alone were ineffective for removal pathogens and even embryos could remained infected although addition of antibiotics to the washing media $[43,45$, 57]. Herpes virus usually can be removed by using trypsin treatment and although trypsin treatment must not be regarded as a general disinfectant, maybe should we also think to an additional treatment for such a bacterium like $M$. paratuberculosis.

Nevertheless, washing of the embryos may be considered as the best way to eliminate different kinds of pathogenic or ubiquitous agents (slightly attached to the zona pellucida or present in the flushing fluids) and the fundamental rule expressed by the IETS a few years ago can be generally applied: If the ZP of the embryos is intact and if the embryos are processed according to the IETS recommendations, then ruminant and swine ZP-intact embryos do not appear to be a vehicle for the transmission of most infectious agents.

\subsubsection{Prevention measures}

The sanitary procedures associated with in vivo production of embryos have been described in the IETS manual. Their recommendations about the selection of the donor female, the sanitary handling of embryos, the washing procedure of embryos and the general hygiene practices (laboratory sanitation, culture medium, sterilization of material) should assure ET teams of the risk of disease transmission via embryo transfer [50].

\subsection{In vitro produced embryos}

The results obtained for in vivo produced embryos cannot be transposable to in vitro produced embryos. It is well recognized that IVF-generated embryos differ morphologically and physiologically from embryos fertilized in vivo. For example, IVF embryos are less compacted and may have a reduced number of cells. There may also be differences in the structure of the zona pellucida. These differences are also noticeable in terms of viability, freezability or speed of development that are significantly reduced for IVF embryos due to differences in ZP structure. ZP in IVF system can be considered as immature and thus the adherence between pathogen agent and embryo seems to be more important.

The structural aspects of the bovine zona pellucida of IVF embryos and in vitro matured (IVM) oocytes have been recently studied by several authors with scanning electron microscopy and fluorescent microspheres. Vanroose et al. [62] concluded that the intact bovine ZP of IVM oocytes and IVF embryos is constructed in such a way that BVDV and BHV-1 should not be able to traverse the $\mathrm{ZP}$ and reach the embryonic cells. However, it appears that few small viruses like BVDV can be caught in the outer layers of the $\mathrm{ZP}$ and contaminate the embryo at hatching. Moreover, Bielanski and Surujballi [17] have observed Leptospira 
hardjo in the pores, matrix and channels of $\mathrm{ZP}$ and in the embryonic cells, indicating the ability of these pathogenic agents to attach the $\mathrm{ZP}$ or penetrate into the embryos.

\subsubsection{Risks of contamination of the oocytes}

The origin of the oocytes is of considerable importance in the sanitary risks associated with production of in vitro embryos. The oocytes are collected either by ovum pick up (OPU) in live donor females or by puncture of slaughterhouse ovaries. With OPU, oocytes are collected from the ovaries of identified donor females with a well defined health status and oocytes can easily be treated separately if necessary. On the contrary, ovaries from the slaughterhouse are randomly collected, so that the donor females may present a potential risk of clinical or subclinical disease. Thereafter, ovaries are pooled for transportation to the IVF laboratory and consequently the pool of oocytes undergoes IVM, IVF and IVC methods.

At collection, the oocytes used for IVF are surrounded by cumulus cells. As a consequence, contamination can directly come from the oocytes or be linked to the surrounding cells. The intrafollicular oocyte can incur either genomic or cellular contamination. Genomic contamination has never been highlighted [33] and intracellular contamination has only been reported for the Porcine parvovirus [2], Campylobacter fetus [15] or Leptospira hardjo [11, 17]. Indeed, the role of the surrounding cells is of great importance in the contamination process during IVF. Pathogens, such as BVDV or BHV-1 can contaminate follicular fluid, granulosa and cumulus cells and even cells from the ovarian stroma [21]. Thereafter, these pathogens can bind to the $\mathrm{ZP}$ and penetrate into the oocyte during fertilisation. Most studies have reported lower fertilisation and development rates $[5,7,31$, $32,60]$, which may depend on the infectious dose [60] and the strains of the pathogens
[59]. Nevertheless, the development of embryos is possible and could lead to disease transmission via ET.

\subsubsection{Risks of disease transmission via contaminated IVF embryos}

As well as for in vivo produced embryos, the risks of disease transmission via ET is conditioned by the possibility to remove the pathogens from the ZP before transfer. The washing procedure recommended by IETS has been tested by many authors after experimental exposure of the oocytes to different pathogens, such as the Bluetongue virus [36], BHV-1 [5, 16, 31], BVDV [10, 20, 22, 54, 58], FMDV [39] and bacteria such as Actinomyces pyogenes bovis, E. coli and Streptococcus agalactiae $[11,43]$. All these studies have shown that the washing procedure was ineffective in removing viruses from IVF embryos, even if a reduction of the infection rate has been observed after a standard trypsin treatment for BHV-1 [17] and BVDV [58]. Bielansky et al. [16], for instance showed that "BVDV may be associated with washed and unwashed embryos and may persist through the IVF process". Similarly, bacteria were not removed effectively by washing alone, but antibiotics had to be added to the in vitro culture media to remove or kill them.

The conclusions are different from the in vivo embryos. It is important to notice that all studies reported the effects of an artificial exposure to the pathogen, with high infectious doses and exposure time. Guérin et al. [31] have observed that IVF embryos remained infected after washing above a threshold dose of viral exposure. Moreover, conflicting results were obtained with oocytes originating from infected donors. Some studies confirmed the insufficient effects of washing on IVF embryos infected with BHV-1 [9], BVDV [66], whereas no evidence of pathogen after washing was observed with BVDV [8]. The discrepancies between these results raise doubts on the transposition of in vitro contamination 
to natural infected animals and further studies are needed to clear the risks of disease transmission through transfer of in vitro embryos produced from natural contaminated donor females.

\subsubsection{Prevention measures}

Until it has been established that the oocytes that are infected are non-viable and that there is an effective disinfection method for IVF embryos, the only way to prevent the potential transmission of pathogens through embryo transfer is to control the health status of donor cows. As a consequence, the herd of origin of the donor female should be free of signs of contagious disease and should comply with the sanitary standards of the country. The donor female should be free of tuberculosis, leukosis and brucellosis, as well as BVD and IBR, in view of the potential for the introduction of these viruses into the IVF system [42]. However, this measure is very difficult to apply for slaughterhouse ovaries, because their sanitary statuses are generally not guarantied. Consequently, each IVF laboratory should separately process oocytes and embryos from slaughterhouses and from OPU.

For OPU oocytes, extended recommended procedures would be suitable: (1) serological control of donor cows; (2) control of biological products; (3) quality control for Embryo Production Teams; (4) use of high microbiological quality semen. If the oocytes are collected from slaughterhouse ovaries, the risks are higher but quality controls on biological products and semen and on procedures with a quality control of Embryo Production Teams should be performed to guarantee such embryos. To be efficient, control procedures must be precisely defined for each pathogen (or group of pathogens).

So far, washing embryos has been considered as the best way to eliminate the pathogenic agents from the embryos. In the case of IVF embryos, there is some evidence that the procedure may be insufficient to completely remove the pathogens from the ZP. However, the experimental conditions have generally tested severe contamination protocols and the washing procedure recommended by the IETS remains a good way to decrease or eliminate some pathogens, especially when associated with the following additional disinfection methods: (1) trypsin treatment $(0.25 \%$ for $90 \mathrm{~s})$ for a more effective removal of pathogens such as BHV-1, without negative effects on the developmental rate of the embryos [16]; (2) treatment with biochemical and biological substances like hematoporphyrin derivative active on BHV-1 and BVDV [4, 13]; (3) antibiotic treatment for the removal of bacteria like Actinomyces pyogenes bovis, E. coli and Streptococcus agalactiae [43].

\section{SANITARY RISKS ASSOCIATED WITH ENVIRONMENTAL CONDITIONS}

Numerous contaminations may result from the serum or media used for the culture or the handling of embryos. Contaminations can also be added during the manipulation of embryos (collection of the oocytes or embryos, washing, culture or transfer).

\subsection{Somatic cells used for co-culture}

For somatic cells, the preliminary results demonstrate that these tissues are sometimes contaminated by various pathogens. Therefore, additional risks may result in the use of co-culture cells obtained from the ovaries or oviducts collected in the slaughterhouse with an unknown health status. Oviductal cells from slaughterhouse material can be contaminated with BVDV or BHV-1 [14], so that the co-culture system may induce a contamination to initially healthy oocytes or embryos. 
As a prevention measure, the preparation in the near future of a fully synthetic media appears to be the most reliable and efficient measure to comply with sanitary security. When systems of co-culture are used, the best way to control sanitary risks is to use established cell lines, which can be tested before use for the presence of pathogens.

\subsection{Fetal calf serum and products from animal origin}

Various media containing products of animal origin are used for the collection, handling, washing, cryopreservation, in vitro culture of embryos and also represent non negligible sanitary risk. Most particularly, fetal calf serum can be contaminated with viruses, such as BVDV [33, 47]. Irradiation of commercial sera may limit those risks, but this procedure is not always applied. In the case of IVF systems, all biological products should be tested for the presence of BVDV and BHV-1 and sera should be inactivated and tested again before use [42]. To conclude, application of the IETS recommendations reduces the sanitary risks related to products from animal origin, but the best way to avoid risks of contamination would be to replace sera by substitutes.

\subsection{Bacterial contaminations}

The presence of different bacterial strains usually considered as ubiquitous pathogens has been noted on some occasions (in particular, Staphylococcus spp., Streptococcus spp., Pseudomonas spp., Bacillus spp.). These bacteria species are common contaminants of bovine semen or the female genital tract (including vaginal mucosa and oviductal cells), but they are also present in the environment or even sometimes in the antibiotic powder usually added to the culture media. These bacteria may invade the IVF system including the oviductal cells used for co-culture of embryos, which leads to reduced fertilisation rates and is usually followed by degeneration and high rates of embryonic death (Marquant-Le Guienne, unpublished observations).

The hygienic conditions associated with manipulation is also of great interest. Related to that particular point, a sanitary control of ET teams working in the field has been developed in France since 1986. This quality control is based on the total bacterial count and identification of various pathogens including BVDV and BHV-1 from flushing and washing media and embryo samples. The preventive measures and special procedures defined in the IETS manual by Nibart et al. [42] should be applied to in vitro production units to lower the sanitary risks associated with in vitro production.

\section{CONCLUSION}

Even if further experiments are still needed for some pathogens, it is well established that in vivo produced embryos are associated with low risk if handling is performed according to recommended IETS procedures. The risks associated with IVF embryos are more difficult to assess. On the one hand, the particular ability of pathogens to attach the zona pellucida of IVF embryos must be taken into account and extended recommended controls for donor cows should be systematically performed before OPU. On the other hand, sanitary controls are necessary on all the biological products used in the media or culture system. In any case, it is important to use semen with a high microbiological quality. Some incertitude remains with the efficient disinfection methods for IVF embryos and prions. In particular, field studies are still necessary to confirm experimental studies. However, without focusing our attention on more questionable agent, it clearly appears that ET remains the more safety way to transfer genes and also the best way to prevent some diseases transmission. 


\section{REFERENCES}

[1] Allietta M., Marquant-Leguienne B., Thibier M., The effect of neutralization of BVD/MD virus present in bovine semen on the IVF and development of bovine embryos, Theriogenology 43 (1995) 156.

[2] Bane D.P., James J.E., Molitor T.W., In vitro exposure of preimplantation porcine embryos to porcine parvovirus, Theriogenology 33 (1990) 553-561.

[3] Barrios D.R., Adams L.G., Failure to isolate brucella abortus from embryos or ova from culture-positive superovulated cows, Theriogenology 29 (1988) 253-361.

[4] Bielanski A., Hare W.C., Investigation of some antimicrobial procedures on the in vitro development of early murine embryos aimed toward developing methods for the disinfection of mammalian embryos prior to transfer, J. In Vitro Fert. Embryo Transf. 8 (1991) 24-32.

[5] Bielanski A., Dubuc C., In vitro fertilization of bovine oocytes exposed to bovine herpesvirus 1 (BHV1), Reprod. Dom. Anim. 28 (1993) 285-288.

[6] Bielanski A., Loewen K.S., In vitro fertilization of bovine oocytes with semen from bulls persistently infected with bovine viral diarrhea virus, Anim. Reprod. Sci. 35 (1994) 183-189.

[7] Bielanski A., Dubuc C., In vitro fertilization and culture of ova from heifers infected with bovine herpesvirus 1 (BHV1), Theriogenology 41 (1994) 1211-1217.

[8] Bielanski A., Dubuc C., In vitro fertilization of ova from cows experimentally infected with a non-cytopathic strain of bovine viral diarrhea virus, Anim. Reprod. Sci. 38 (1995) 215-221.

[9] Bielanski A., Stewart R.B., Ubiquitous microbes isolated from in vitro fertilization (IVF) system, Theriogenology 45 (1996) 269.

[10] Bielanski A., Jordan L., Washing or washing and trypsin treatment is ineffective for removal of noncytopathic bovine viral diarrhea virus from bovine oocytes or embryos after experimental viral contamination of an in vitro fertilization system, Theriogenology 46 (1996) 1467-1476.

[11] Bielanski A., Surujballi O., Association of leptospira borgpetersenii serovar hardjo type hardjobovis with bovine ova and embryos produced by in vitro fertilization, Theriogenology 46 (1996) 45-55.

[12] Bielanski A., Eaglesome M.D., Ruhnke H.L., Hare W.C., Isolation of Mycoplasma bovis from intact and microinjected preimplantation bovine embryos washed or treated with trypsin or antibiotics, J. In Vitro Fert. Embryo. Transf. 6 (1989) 236-241.
[13] Bielanski A., Dubuc C., Hare W.C.D., Myers D.J., Eaglesome M.D., Inactivation of bovine herpesvirus 1 and bovine viral diarrhea virus in association with preimplantation bovine embryos using photosensitive agents, Theriogenology 38 (1992) 633-644.

[14] Bielanski A., Loewen K.S., Del Campo M.R., Sirard M.A., Willadsen S.M., Isolation of bovine herpesvirus 1 (BHV1) and bovine viral diarrhea virus (BVDV) in association with the in vitro production of bovine embryos, Theriogenology 40 (1993) 531-538.

[15] Bielanski A., Sampath M., Gradil C., Eaglesome M.D., Garcia M.M., In vitro fertilization of bovine ova in the presence of campylobacter fetus subsp. Veneralis, Reprod. Dom. Anim. 29 (1994) 488-493.

[16] Bielanski A., Lutze-Wallace C., Sapp T., Jordan L., The efficacy of trypsin for disinfection of in vitro fertilized bovine embryos exposed to bovine herpesvirus 1, Anim. Reprod. Sci. 47 (1997) 1-8.

[17] Bielanski A., Surujballi O., Golsteyn T.E., Tanaka E., Sanitary status of oocytes and embryos collected from heifers experimentally exposed to Leptospira borgpetersenii serovar hardjobovis, Anim. Reprod. Sci. 54 (1998) 65-73.

[18] Bielanski A, Hutchings D, Turcotte C., Status of embryos and ova collected from superovulated heifers experimentally, infected with Mycobacterium bovis, Proceeding IETS, Québec 51 (1999) 270.

[19] Bielanski A., Devenish J., Phipps-Todd B., Effect of Mycoplasma bovis and Mycoplasma bovigenitalium in semen on fertilization and association with in vitro produced morula and blastocyst stage embryos, Theriogenology 53 (2000) 1213-1223.

[20] Booth P.J., Collins M.E., Jenner L., Prentice H., Ross J., Badsberg J.H., Brownlie J., Isolation of virus from IVF bovine embryos infected in vitro with non-cytopathogenic bovine viral diarrhoea virus, following washing using IETS recommended procedures, Proceeding AETE, Lyon 9-10 Sept. 1994, Vol. 154.

[21] Booth P.J., Stevens D.A., Collins M.E., Brownlie J., Detection of bovine viral diarrhoea virus antigen and RNA in oviduct and granulosa cells of persistently infected cattle, J. Reprod. Fertil. 105 (1995) 17-24.

[22] Booth P.J., Collins M.E., Jenner L., Prentice H., Ross J., Badsberg J.H., Brownlie, J., Association of non-cytopathogenic BVDV with bovine blastocysts: effects of washing, duration of viral exposure and degree of blastocyst expansion, Vet. Rec. 144 (1999) 150-152.

[23] Bowen R.A., Howard T.H., Elsden R.P., Seidel G.E.J., Embryo transfer from cattle infected with bluetongue virus, Am. J. Vet. Res. 44 (1983) 1625-1628. 
[24] Britton A.P., Johnson W.H., The recovery of ureaplasmas from bovine embryos following in vitro exposure and ten washes, Theriogenology 30 (1988) 997-1003.

[25] Del Campo M.R., Tamayo R., Embryos transfer from brucellosis-positive donors: a field trial, Theriogenology 27 (1987) 221.

[26] Eaglesome M.D., Mitchell D., Betteridge K.J., Randall G.C., Singh E.L., Samagh B.S., Hare W.C., Transfer of embryos from bovine leukaemia virus-infected cattle to uninfected recipients: preliminary results, Vet. Rec. 111 (1982) 122-123.

[27] Foote W.C., Clark W., Maciulis A., Call J.W., Hourrigan J., Evans R.C., Marshall M.R., de Camp M., Prevention of scrapie transmission in sheep, using embryo transfer, Am. J. Vet. Res. 54 (1993) 1863-1868.

[28] Foster J.D., McKelvey W.A., Mylne M.J., Williams A., Hunter N., Hope J., Fraser H., Studies on maternal transmission of scrapie in sheep by embryo transfer, Vet. Rec. 130 (1992) 341-343

[29] Foster J., McKelvey W., Fraser H., Chong A., Ross A., Parnham D., Goldmann W., Hunter N., Experimentally induced bovine spongiform encephalopathy did not transmit via goat embryos, J. Gen. Virol. 80 (1999) 517-524.

[30] Guérin B., Marquant-Leguienne B., Chaffaux S., Harlay T., Allietta M., Thibier M., Contamination des ovocytes et des embryons fécondés in vitro après infection expérimentale de vaches donneuses par le virus herpès bovin de type 1 (BHV1), Rec. Med. Vet. 165 (1989) 827-833.

[31] Guérin B., Marquant-Leguienne B., Allietta M., Harlay T., Thibier M., Effets de la contamination par le BHV1 sur la maturation et la fécondation in vitro des ovocytes de bovins, Rec. Med. Vet. 166 (1990) 911-917.

[32] Guérin B., Chaffaux S., Marquant-Leguienne B., Allietta M., Thibier M., IVF and IV culture of bovine embryos using semen from a bull persistently infected with BVD, Theriogenology 37 (1992) 217.

[33] Guérin B., Nibart M., Marquant-Leguienne B., Humblot P., Sanitary risks related to embryo transfert in domestic species, Theriogenology 47 (1997) 33-42.

[34] Kirkland P.D., Richards S.G., Rothwell J.T., Stanley D.F., Replication of bovine viral diarrhoea virus in the bovine reproductive tract and excretion of virus in semen during acute and chronic infections, Vet. Rec. 128 (1991) 587-590.

[35] Kirkland P.D., McGowan M.R., Mackintosh S.G., Moyle A., Insemination of cattle with semen from a bull transiently infected with pestivirus, Vet. Rec. 140 (1997) 124-127.

[36] Langston N.L., Stringfellow D.A., Garrett G., Failure to wash bluetongue virus from bovine
IVF embryos, Proceedings IETS, Canada 51 (1999) 273.

[37] Le Tallec B., Guérin, B., Proposition d'un plan de contrôle et d'éradication de la paratuberculose dans la filière insémination artificielle, Élevage et Insémination 290 (1999) 4-15

[38] Le Tallec B., Guérin B., Recent advances in paratuberculosis should be put at contribution and used for a plan of control and eradication within the inseminations centres, 12th European AI VETS Meeting, 2000, pp. 1-6.

[39] Marquant-Leguienne B., Rémond M., Thibier M., Exposure of in vitro-produced bovine embryos to foot-and-mouth disease virus, Theriogenology 50 (1998) 109-116.

[40] McVicar J.W., Singh E.L., Hare W.C., Embryo transfer as a means of controlling the transmission of viral infections - VIII. Failure to detect foot-and-mouth disease viral infectivity associated with embryos collected from infected donor cattle, Theriogenology 26 (1986) 595-603.

[41] Mebus C.A., Singh E.L., Embryo transfer as a means of controlling the transmission of viral infections - XIII. Failure to transmit foot-andmouth disease virus through the transfert of embryos from viremic donors, Theriogenology 35 (1991) 435-441.

[42] Nibart M., Marquant-Leguienne B., Humblot P., General sanitary procedures associated with in vitro production of embryos, Manuel of the IETS, 3rd edn., International Embryo Transfer Society, 1998, pp. 67-84.

[43] Otoi T., Tachikawa S., Kondo S., Suzuki T., Effect of antibiotics treatment of in vitro fertilized bovine embryos to remove adhering bacteria, J. Vet. Med. Sci. 54 (1992) 763-765.

[44] Otoi T., Tachikawa S., Kondo S., Suzuki T., Effect of washing, antibiotics and trypsin treatment of bovine embryos on the removal of adhering K99+ Escherichia coli, J. Vet. Med. Sci. 55 (1993) 1053-1055.

[45] Riddell K.P., Stringfellow D.A., Gray B.W., Riddell M.G., Galik P.K., Antibiotic treatment of bovine embryos, J. Assist. Reprod. Genet. 10 (1993) 488-491.

[46] Rohde R.F., Shulaw W.P., Hueston W.D., Bech-Nielsen S., Haibel G.K., Hoffsis G.F., Isolation of Mycobacterium paratuberculosis from washed bovine ova after in vitro exposure, Am. J. Vet. Res. 51 (1990) 708-710.

[47] Rossi C.R., Bridgman C.R., Kiesel G.K., Viral contamination of bovine fetal lung cultures and bovine fetal serum, Am. J. Vet. Res. 41 (1980) 1680-1681.

[48] Singh E.L., Thomas F.C., Papp-Vid G., Eaglesome M.D., Hare W.C., Embryo transfer as a means controlling the transmission of viral infections - II. The in vitro exposure of preimplantation bovine embryos to infectious bovine rhinotracheitis virus, Theriogenology 18 (1982) 133-140. 
[49] Singh E.L., McVicar C., Hare W.C., Mebus C.A., Embryo transfer as a means controlling the transmission of viral infections - II. The in vitro exposure of bovine and porcine embryos to foot- and- mouth disease virus, Theriogenology 26 (1986) 587-593.

[50] Stringfellow D.A., Seidel G.E., A procedural guide and general information for the use of embryo transfer technology emphasizing sanitary precautions, Manual of the IETS, 3rd edn., International Embryo Transfer Society, 1998, pp. 1-170.

[51] Stringfellow D.A., Howell Vickie L., Schurrenberger P.R., Investigations into the potential for embryo transfer from Brucella abortus infected cows without transmission of infection, Theriogenology 18 (1982) 733-743.

[52] Stringfellow D.A., Wolfe D.F., Lauerman L.H., Sparling P.H., Resistance of preimplantation bovine embryos to infection with Brucella abortus, Am. J. Vet. Res. 47 (1986) 1924-1927.

[53] Stringfellow D.A., Lauerman L.H., Nasti K.B., Galik P.K, Trypsin treatment of bovine embryos after in vitro exposure to infectious bovine rhinotracheitis virus or bovine herpesvirus-4, Theriogenology 34 (1990) 427-434.

[54] Stringfellow D.A., Riddell K.P., Galik P.K., Damiani P., Bishop M.D., Wright J.C., Quality controls for bovine viral diarrhea virus-free IVF embryos, Theriogenology 53 (2000) 827-839.

[55] Thibier M., Nibart M., Disease control and embryo importations, Theriogenology 27 (1987) 37-47.

[56] Thomas F.C., Singh E.L., Hare W.C., Embryo transfer as a means of controlling viral infections - III. Non transmission of bluetongue virus from viremic cattle, Theriogenology 19 (1983) 425-431.

[57] Thomson M.S., Stringfellow D.A., Lauerman L.H., Adherence of Haemophilus somnus to bovine embryos after in vitro exposure, Am. J. Vet. Res. 49 (1988) 63-66.

[58] Trachte E., Stringfellow D., Riddell K., Galik P., Riddell M.J., Wright J., Washing and trypsin treatment of in vitro derived bovine embryos exposed to bovine viral diarrhea virus, Theriogenology 50 (1998) 717-726.

[59] Vanroose G., Nauwynck H., Van Soom A., Vanopdenbosch E., de Kruif A., Replication of cytopathic and noncytopathic bovine viral diarrhea virus in zona-free and zona-intact in vitroproduced bovine embryos and the effect on embryo quality, Biol. Reprod. 58 (1998) 857-866.

[60] Vanroose G., Nauwynck H., Van Soom A., Vanopdenbosch E., de Kruif A., Effect of bovine herpesvirus- 1 or bovine viral diarrhea virus on development of in vitro-produced bovine embryos, Mol. Reprod. Dev. 54 (1999) 255-263.

[61] Vanroose G., Nauwynck H., Van Soom A., Vanopdenbosch E., de Kruif A. Effect of the interaction between bovine herpesvirus- 1 and sperm cells on the in vitro fertilization of bovine oocytes, Proceedings AETE, Lyon, 1999, p. 234.

[62] Vanroose G., Nauwynck H., Soom A.V., Ysebaert M.T., Charlier G., Van Oostveldt P.V., de Kruif A., Structural aspects of the zona pellucida of in vitro-produced bovine embryos: a scanning electron and confocal laser scanning microscopic study, Biol. Reprod. 62 (2000) 463-469.

[63] Wang S., Foote W.C., Sutton D.L., Maciulis A., Miller J.M., Evans R.C., Holyoak G.R., Call J.W., Bunch T.D., Taylor W.D., Marshall M.R., Preventing experimental vertical transmission of scrapie by embryo transfer, Theriogenology 56 (2001) 315-327.

[64] Wrathall A.E., Risks of transmitting scrapie and bovine spongiform encephalopathy by semen and embryos, Rev. Sci. Tech. 16 (1997) 240-264.

[65] Wrathall A.E., Brown K.F.D., Ferguson C.A., Embryos and uterine flush fluids from cattle with bovine spongiform encephalopathy are not infective for mice, Proceedings IETS, Nice, 1997, Vol. 47, pp. 384.

[66] Zurovac O., Stringfellow D., Brock K.V., Riddell M.G., Wright J., Noncytopathic bovine viral diarrhea virus in a system for in vitro production of bovine embryos, Theriogenology 41 (1994) 841-853.

To access this journal online: www.edpsciences.org 